\title{
СОВЕТСКИЕ ВОЕННОПЛЕННЫЕ: СКОЛЬКО ИХ БЫЛО И СКОЛЬКО ВЕРНУЛОСЬ?
}

\author{
ПАВЕЛ ПОЛЯН ${ }^{1, *}$
}

\begin{abstract}
В статье рассматриваются демографические аспекты проблематики плена военнослужаших Красной Армии во время Великой отечественной войны: количество взятых в плен (немецкий, финский и румынский), смертность в плену, данные о репатриации. В качестве отдельной подкатегории рассматриваются советские военнопленные - евреи по национальности, ставшие дефакто первыми после 22 июня 1941 г. жертвами Холокоста.

Ключевые слова: плен, советские военнопленные, советские военнопленные-евреи, холокост, смертность в плену, репатриация, компенсация.
\end{abstract}

\section{ДЕБАТЫ О ЧИСЛЕ И СМЕРТНОСТИ}

Шестизначные цифры военнослужащих Красной Армии, захваченных немцами в плен 1941-1942 гг. после таких окружений как Киевское, Брянско-Вязьминское, БелостокскоМинское, Смоленско-Рославльское, Крымское, Кубанско-Донское, Харьковское или Уманьское, поистине беспрецедентны.

В речи, произнесенной Гитлером 11 декабря 1941 г., прозвучала составленная по донесениям войсковых частей и невероятная по своему итогу суммарная цифра военнопленных - 3,8 млн человек. В конце 1941 г. эта цифра была пересмотрена на основании коррекции донесений из лагерей для советских военнопленных, что уменьшило их число почти на 0,5 млн - до 3,35 млн человек. Интересно, что результаты отдельных окружений не пересматривались и при суммировании давали именно 3,8 млн человек. Так что, скорее всего, точнее была именно первая цифра, возможно содержавшая в себе и умерших (как до, так и после регистрации), и тех военнопленных, которых осенью 1941 г. выводили из состояния плена и отпускали домой (таких в зоне ответственности ОКХ Oberkommando des Heeres в 1941 г. было не менее 319 тыс. человек).

\footnotetext{
${ }^{1}$ ИНСТИТУТ ГЕОГРАФИИ РОССИЙСКОЙ АКАДЕМИИ НАУК (РОССИЯ).

*E-MAIL: PAVEL.POLIAN@GMAIL.COM
}

СТАТЬЯ ПОСТУПИЛА В РЕДАКЦИЮ В МАРТЕ 2016 Г. 
К миллиону и больше, видимо, приближался и счет так называемых «окруженцев», т.е. красноармейцев, попавших во вражеское окружение, но не взятых в плен, а сумевших вырваться из окружения к своим. Уже к середине октября 1941 г. таковых, по данным регистрировавшего и фильтровавшего их НКВД, насчитывалось около 660 тыс. человек, а «котлы» к этому времени еще далеко не закончились ${ }^{1}$. К тому же часть «окруженцев» так и не смогла (или не захотела) пробиться к своим. Одни пошли к партизанам, другие осели по деревням: де-юре - на правах родственников (мужей, сыновей) местного гражданского населения, а де-факто - приймаками. Со временем они или попадали в списки на угон в Германию, или присоединялись к партизанам, иногда делали карьеру в оккупационной администрации.

Если вернуться к советским военнопленным, то, согласно данным К. Штрайта, в середине июля 1942 г. их насчитывалось уже 4716903 человек, в январе 1943 г. — 5003697, в феврале 1944 г. - 5637482 и на 1 февраля 1945 г. - 5734528 человек [Streit 1991: 244]². Согласно текущим сводкам ОКХ о количестве военнопленных и военных трофеев, общее число военнопленных и перебежчиков по состоянию на 21 июля 1944 г. насчитывало 5691747 человек $^{3}$.

Первую попытку систематического анализа различных учетов советских военнопленных произвел Р. Оверманнс (таблица 1). Он наметил и проанализировал три разных статистических ряда: 1) донесения отделов Iс (органы военной контрразведки) войсковых соединений, захвативших советских военнослужащих в плен (эти сообщения имеются практически повсеместно и полно, но не существовало такого центрального органа, который сводил бы и вел эти данные в качестве текущей официальной статистики); 2) данные учетов Отдела «Вражеские сухопутные войска/Восток» Верховного главнокомандования сухопутных войск (ОКН/Abteilung Fremde Heere Ost) (именно их, хотя и не полностью, использовал К. Штрайт); 3) сводную оценку вермахта, основывающуюся на 10-дневных сообщениях вооруженных сил, которые затем сводились в помесячную отчетность (основываются, предположительно, на информации от сборных пунктов военнопленных). Внутри вермахта только эта информация и распространялась.

Все три ряда чисел существенно друг от друга отличаются. Первый заканчивается на цифре около 6 млн человек, второй - примерно на 5,75 млн, а третий - примерно на 5,3 млн (она-то и приведена в таблице 1, но с добавлением учета военнопленных в лагерях военных авиации и флота). Естественно было бы предположить, что разница в

1 См. письмо зам. начальника Управления Особого отдела НКВД комиссара госбезопасности С.Р. Мильштейна Л.П. Берии, косвенно датируемое этой датой: «С начала войны по 10-е октября с.г. Особыми отделами НКВД по охране тыла задержано 657.364 военнослужащих, отставщих от своих частей $u$ бежавших с фронта <...>. В числе арестованных Особыми отделами: ипионов - 1505, диверсантов - 308, трусов и паникеров - 2643, дезертиров - 8772, распространителей провокационных слухов - 3987 , самострельщиков - 1671, <..> ВСЕГО: 25878. По постановлению Особых отделов и по приговорам Военных трибуналов расстреляно 10321 человек, из них расстреляно перед строем - 3321 человек» [Буковский 1996: 77-78].

${ }^{2}$ На 30.06.1943 насчитывалось 5419605 военнопленных (BA/MA, RW 4/v.309 b). Начиная со второй половины 1943 г., поступление новых пленных резко сократилось.

${ }^{3} \mathrm{BA} / \mathrm{MA}, \mathrm{RH} 2 / 2773$. 
значительной степени (но не полностью) возникла из-за коррекции статистики вермахта во второй декаде декабря 1941 г.

Таблица 1. Статистика численности советских военнопленных в немецком плену (по Р. Оверманнсу)

\begin{tabular}{|c|c|c|c|c|c|c|c|c|}
\hline \multirow[t]{2}{*}{ Даты } & \multicolumn{2}{|c|}{ Сухопутные войска } & \multicolumn{2}{|c|}{$\begin{array}{c}\text { Военно- } \\
\text { воздушные силы }\end{array}$} & \multicolumn{2}{|c|}{$\begin{array}{c}\text { Военно- } \\
\text { морской флот }\end{array}$} & \multicolumn{2}{|c|}{$\begin{array}{c}\text { Вооруженные силы } \\
\text { (вермахт) }\end{array}$} \\
\hline & aбс. & кум. & абс. & кум. & абс. & кум. & абс. & кум. \\
\hline 30.06 .1941 & 112784 & 112784 & & 0 & 0 & 0 & 112784 & 112784 \\
\hline 31.07 .1941 & 701046 & 813830 & 0 & & 0 & 0 & 701046 & 813830 \\
\hline 31.08 .1941 & 698580 & 1492310 & 0 & 0 & 0 & 0 & 698580 & 1492310 \\
\hline 30.09 .1941 & 992110 & 2481513 & 762 & 1748 & 0 & 0 & 992872 & 2483261 \\
\hline 31.10 .1941 & 1037778 & 3528046 & 936 & 2684 & 64 & 64 & 1038778 & 3530794 \\
\hline 30.11 .1941 & 291934 & 3819980 & 236 & 2920 & 0 & 64 & 292170 & 3822964 \\
\hline 31.12 .1941 & 75440 & 3367206 & 48 & 2968 & 2599 & 2663 & 78087 & 3372837 \\
\hline 31.01 .1942 & 44082 & 3411288 & 10 & 2978 & 0 & 2663 & 44092 & 3416928 \\
\hline 28.02 .1942 & 26734 & 3438022 & 8 & 2985 & 7 & 2670 & 29726 & 3443677 \\
\hline 31.03 .1942 & 37700 & 3475722 & 350 & 3335 & 0 & 2670 & 38050 & 3481727 \\
\hline 30.04 .1942 & 29786 & 3505508 & 0 & 3335 & 0 & 2670 & 29786 & 3511513 \\
\hline 31.05 .1942 & 259215 & 3764723 & 0 & 3335 & 0 & 2670 & 259215 & 3770728 \\
\hline 30.06 .1942 & 227408 & 3992131 & 325 & 3660 & 0 & 2670 & 227733 & 3998461 \\
\hline 31.07 .1942 & 363357 & 4355488 & 0 & 3660 & 0 & 2670 & 363357 & 4361818 \\
\hline 31.08 .1942 & 297825 & 4653313 & 89 & 3749 & 0 & 2670 & 297914 & 4659732 \\
\hline 30.09 .1942 & 113727 & 4767040 & 248 & 3997 & 0 & 2670 & 113975 & 4773707 \\
\hline 31.10 .1942 & 52048 & 4819088 & 512 & 4509 & 0 & 2670 & 52560 & 4826267 \\
\hline 30.11 .1942 & 31907 & 4850995 & 163 & 4672 & 0 & 2670 & 32070 & 4858337 \\
\hline 31.12 .1942 & 31282 & 4882277 & 122 & 4794 & 0 & 2670 & 31404 & 4889741 \\
\hline 31.01 .1943 & 19091 & 4901368 & 365 & 5159 & 0 & 2670 & 19456 & 4909197 \\
\hline 28.02 .1943 & 17208 & 4918576 & 85 & 5244 & 0 & 2670 & 17293 & 4926490 \\
\hline 31.03 .1943 & 33822 & 4952398 & 175 & 5419 & 0 & 2670 & 33997 & 4960487 \\
\hline 30.04 .1943 & 7080 & 4959478 & 112 & 5531 & 0 & 2670 & 7192 & 4967679 \\
\hline 31.05 .1943 & 6820 & 4966298 & 164 & 5695 & 0 & 2670 & 6984 & 4974663 \\
\hline 30.06 .1943 & 5692 & 4971990 & 252 & 5947 & 0 & 2670 & 5944 & 4980607 \\
\hline 31.07 .1943 & 53577 & 50 & 284 & 6231 & 0 & 2670 & 53861 & 5034468 \\
\hline 31.08 .1943 & 23454 & 5031539 & 278 & 6509 & 0 & 2670 & 23732 & 5040718 \\
\hline 30.09 .1943 & 10857 & 5040878 & 191 & 6700 & 0 & 2670 & 11048 & 5050248 \\
\hline 31.10 .1943 & 25384 & 5066262 & 183 & 6883 & 0 & 2670 & 25567 & 5075815 \\
\hline 30.11 .1943 & 17627 & 5083889 & 106 & 6989 & 0 & 2670 & 17733 & 5093548 \\
\hline 31.12 .1943 & 22837 & 5106726 & 83 & 7072 & 0 & 2670 & 22920 & 5116468 \\
\hline 31.01 .1944 & 16001 & 5122727 & 114 & 7186 & 0 & 2670 & 16115 & 5132583 \\
\hline 29.02 .1944 & 19329 & 5142056 & 114 & 7300 & & 2670 & 19443 & 5152026 \\
\hline 31.03 .1944 & 9258 & 5151314 & 140 & 7440 & & 2670 & 9398 & 5161424 \\
\hline 30.04 .1944 & 11316 & 5162630 & 117 & 7557 & & 2670 & 11433 & 5172857 \\
\hline 31.05 .1944 & 18644 & 5181274 & 57 & 7614 & & 2670 & 18701 & 5191558 \\
\hline 30.06 .1944 & & 5184075 & 70 & 7684 & & 2670 & 2871 & 5194429 \\
\hline 31.07 .1944 & 1211 & 5185286 & 96 & 7780 & & 2670 & 1307 & 5195736 \\
\hline 31.08 .1944 & 12509 & 5197795 & 41 & 7821 & & 2670 & 12550 & 5208286 \\
\hline 30.09 .1944 & 12452 & 5210247 & 106 & 7927 & & 2670 & 12558 & 5220844 \\
\hline 31.10 .1944 & 9164 & 5221212 & 61 & 7988 & & 2670 & 9225 & 5231870 \\
\hline 30.11 .1944 & 6085 & 5226392 & 0 & 7988 & & 2670 & 6085 & 5237050 \\
\hline 31.12 .1944 & 3781 & 5231057 & 201 & 8189 & & 2670 & 3982 & 5241916 \\
\hline 31.01 .1945 & 8652 & 5237660 & 165 & 8354 & & 2670 & 8817 & 5248684 \\
\hline 28.02 .1945 & 8222 & 5245882 & 0 & 8354 & & 2670 & 8222 & 5256906 \\
\hline Итого & & 5245882 & & 8354 & & 2670 & & 5256906 \\
\hline
\end{tabular}

Источники: Bnepвые - [Overmans, Hilger, Polian 2012: 863-865]. Таблица составлена Р. Оверманнсом. Данные из следующих источников: OKW/WFSt/Org (Vb), Beurteilung der personellen und materiellen Rüstungslage der Wehrmacht (Monatsmeldung) [Оченка персонального и материального положения Вооруженных сил, ежемесячные сообщения / Генерал-квартирмейстер, 10-дневная отчетность] 
(BA/MA. RW 6/v. 543, RW 6/v. 544, RW 6/v. 545, RW 6/v. 546, RW 6/v. 547, RW 6/v. 548, RM 7/810); Oberbefehlshaber der Luftwaffe / Generalquartiermeister, 10-Tagemeldungen der Wehrmachtteile [Главнокомандующий военно-воздушными силами / Генерал-квартирмейстер, 10-дневная отчетность] (BA/MA. RW 19/1387, RW 19/1389); Oberkommando der Kriegsmarine/ Seekriegsleitung, 10-Tagemeldungen der Wehrmachtteile [Высшее командование ВМФ / Командование морскими операциями, 10-дневная отчетность] (BA/MA. RM 7/800, RM 7/801, RM 7/802, RW 19/1387, RW 19/1389, RW 19/1390, RW 19/1392).

Примечания: Абс. - абсолютно; кум. - кумулятивно.

ВА/МА-Федеральный архив / Военный архив, Фрайбург.

Расчетные значения даются курсивом; данные, извлеченные из архивов, отображаются прямым шрифтом; итоговые значения не всегда совпадают с суммой составляющих их элементов из-за ошибок в исходных данных; данные для сухопутных войск являются оценочными вплоть по сентябрь 1941 г. включительно; начиная с июля 1944 г. данные для сухопутных войск являются во все большей мере неполными.

Очевидно, что к тому же статистическому источнику, что и у Р. Оверманса, восходят данные А. Даллина [Dallin 1958] по состоянию на 1 мая 1944 г., примечательные и ценные своей детальностью и структурированностью (таблица 2).

Таблица 2. Советские военнопленные на 1 мая 1944 г., тыс.

\begin{tabular}{|c|c|c|c|c|}
\hline & \multirow{2}{*}{$\begin{array}{c}\text { В зоне } \\
\text { ответственности } \\
\text { ОКХ, тыс. человек }\end{array}$} & \multirow{2}{*}{$\begin{array}{c}\text { В зоне } \\
\text { ответственности } \\
\text { ОКВ, тыс. человек }\end{array}$} & \multicolumn{2}{|c|}{ Всего } \\
\hline & & & Тыс. человек & $\%$ \\
\hline Всего & 2050 & 3110 & 5160 & 100,0 \\
\hline Из них: & & & & \\
\hline А. находятся в лагерях & 175 & 878 & 1053 & 20,4 \\
\hline в том числе работают & 151 & 724 & 875 & 17,0 \\
\hline Б. освобождено из плена & & & & \\
\hline $\begin{array}{l}\text { или принято на военную } \\
\text { службу }\end{array}$ & 535 & 283 & 818 & 15,9 \\
\hline В. умерло в лагерях & 845 & 1136 & 1981 & 38,4 \\
\hline Г. остальные & 495 & 813 & 1308 & 25,3 \\
\hline в том числе бежало & Н.д. & 67 & 67 & 1,3 \\
\hline казнено & Н.д. & 473 & 473 & 9,1 \\
\hline умерло в транзитных & & & & \\
\hline $\begin{array}{l}\text { лагерях или не } \\
\text { зарегистрировано }\end{array}$ & 495 & 273 & 768 & 14,9 \\
\hline
\end{tabular}

Источник: [Ueberschär, Wette 1984: 364-366] со ссылкой на Nachweisung des Verbleibes der sowjetischen Kriegsgefangenen nach dem Stand vom 1.05.1944 BA/MA, RH 2 / v.262.

Советские военные историки, оспаривая все эти цифры, утверждают, что в них якобы зачтены такие многочисленные контингенты, как комбатанты (ополченцы, партизаны, подпольщики), сотрудники партийных и советских органов, мобилизованные, попавшие в окружение вместе с войсками беженцы, отнесение которых к категории пленных неправомерно. На это приходится возразить: обхождение, например, с арестованными партизанами и подпольщиками было принципиально иным, чем с военнопленными. Их рассматривали как бандитов, как уголовных преступников и после доказательств военно-полевым судом их виновности и утверждения смертного приговора 
командиром немедленно расстреливали или вешали. При оправдательном приговоре с подсудимым обращались как с гражданским интернированным лицом ${ }^{4}$.

Актуальная официальная советско-российская оценка отличается от немецкой более чем на 1,5 млн человек - 4059 тыс., а с учетом без вести пропавших - 4559 тыс. человек [Россия и СССР в войнах... 2001: 462]. К сожалению, критикуя немецкую статистику, советские военные историки не раскрывают ни источники, ни методику расчета этих альтернативных результатов, так что говорить о корректном сравнении их цифр с немецкими затруднительно ${ }^{6}$.

По официальным данным, 1368,8 бывших советских военнопленных в конце войны или после ее окончания репатриировалось из плена, 939,7 тыс. человек были вторично призваны в ряды Красной Армии на освобожденной от врага территории, а 673 тыс., по немецким данным, умерло в плену. «Недостающие» 1,1 млн человек, по оценке историков Генштаба, распределяются фактически между умершими в плену и пропавшими без вести ${ }^{7}$

По данным на 1 мая 1944 г., в зоне ответственности ОКВ (т.е. на территории самого Рейха, Генерал-Губернаторства и Рейхскомиссариатов Украина и Остланд) в общей сложности перебывало 3110 тыс. советских военнопленных, из них 1882 тыс. или 60,5\%, умерли там своей смертью или были казнены (таблица 2). Но еще выше была аналогичная доля в зоне ответственности ОКХ, т.е. в сугубо армейском оккупационном режиме: 1340 из 2050 тыс. человек или $65,4 \%$ !

Лишь 20,4\% военнопленных находилось на эту дату в лагерях, из них около 83\% работали. И хотя в зоне ОКХ этот показатель был еще выше (86,3\%), на нее к 1 мая 1944 г. приходилось всего лишь 17,3\% от общего числа трудившихся военнопленных. Большинство же (724 против 151 тыс. человек) трудились на благо Рейха в зоне ОКВ. Зато по числу отпущенных на свободу и коллаборантов, как, впрочем, и по числу умерших в транзитных лагерях или незарегистрированных военнопленных, перевес - и заметный - за ОКХ: соответственно 535 против 283 тыс. человек и 495 против 273 тыс. человек.

Количество единовременно находившихся в Рейхе военнопленных имело весьма выразительную динамику: по состоянию на 20 октября 1941 г. в Рейхе находилось 350 тыс. советских военнопленных, а на 5 ноября - даже 475 тыс. $^{8}$

\footnotetext{
${ }^{4}$ Наставление о поведении частей в занятых областях при нападении населения: ГАРФ. Ф.Р-7021. Оп.148. Д.199.

5 Как это ни удивительно, но в новейшем и явно претендующем на итоговость 12 -томном издании [Великая отечественная война 2011-2015] масштабы потерь советских военнопленных даже не обсуждаются! В томе 3 «Битвы и сражения, изменившие ход войны» они фигурируют в вынесенных в приложение немецких документах, зато фактически отсутствуют в 900-страничном тексте!

${ }^{6}$ Не говоря уже об оценке комиссии американского генерала Вуда в 4 млн человек [Решин 1994: 158].

${ }^{7}$ Подробнее всего в [Гриф секретности снят... 1993: 338]. По вторично демобилизованным имеется ссылка на: ЦАМО. Ф.19-А. Оп. 2924. Д.7. Л. 87-96; Ф.8А, Оп.1261. Д. 2. Л.50, 57.

${ }^{8}$ Arbeitsstab der Organisation Todt für russischen Kriegsgefangeneneinsatz. Gez. Henne. Berlin, 5.11.1941 (BAP, 46.03, Nr32, B1. 9,10).
} 
Но их судьба, видимо, не сильно отличалась от судьбы тех, кто был вдали от Германии: и те, и другие интенсивно гибли! Так, в январе 1942 г., по данным К. Штрайта, их насчитывалось даже меньше, чем в октябре, - всего 318 тыс. человек

Следует признать, что в первые 8-9 месяцев войны политика вермахта и СД по отношению к советским военнопленным носила все признаки геноциидальности 9 , а сборные пункты, дулаги и шталаги (как на востоке, так и в Рейхе) являлись самыми настоящими лагерями уничтожения. Изнурительный, голодный режим содержания в них и трудоиспользования военнопленных приводил к не знающей прецедентов смертности, а иногда и к таким отчаянным крайностям, как каннибализм [Черноглазова 1996: 124] ${ }^{10}$. Дополнительным испытанием на выживаемость была и сама дорога в Рейх, в особенности в зимнее время в открытых вагонах.

Но спустя год, в январе 1943 г., когда геноциидальность немецкой политики по отношению к военнопленным ослабла, их число составило уже 640948 человек, в январе 1944 г. - 739153 и в январе 1945 г. - 856804 человек. Максимум же был зафиксирован в декабре 1944 г. - 868321 человек [Streit 1991: 244-245] ${ }^{11}$. К концу 1944 г. это были уже практически все наличные, т.е. оставшиеся в живых, советские военнопленные, поскольку в зоне ОКХ их уже не было, а в Генерал-губернаторстве и Протекторате Чехия и Богемия их оставалось не более 60-70 тыс. человек. Тут, конечно, не следует забывать, что около 1 млн военнопленных было к этому времени переведено из плена в различные немецкие соединения, формировавшиеся как в ОКХ, так и в ОКВ, и к концу войны, несмотря на все потери, сосредотачивавшиеся, в основном, в Рейхе ${ }^{12}$.

Итак, если исходить из цифры в 5,7 млн советских военнопленных, то к концу войны в живых из них оставалось самое большее 2,4 млн. Таким образом, остальные 3,3 млн человек (или $57 \%$ !) ${ }^{13}$ умерли или погибли в плену, причем около 2 млн - до февраля 1942 г. [Streit 1991: 244-246]. Если бы можно было сопоставлять динамику смертности советских военнопленных и советских евреев, то, несмотря на отсутствие статистики, едва ли будет преувеличением утверждать: до весны 1942 г. военнопленные определенно «опережали» евреев.

Уцелевшие же распределялись так: статус военнопленного до конца войны сохраняли порядка 900 тыс. человек, более 320 тыс. были распущены по домам осенью 1941

\footnotetext{
${ }^{9}$ Более уместным тут представляется термин стратоцид [Полян 2010]). Этим термином (кажется, впервые) воспользовался Б. Соколов [1998: 26].

${ }^{10}$ В Бобруйском шталаге за каннибализм было расстреляно 28 человек. В Минском от голода и холода в ту зиму умерло не менее 40 тыс. человек.

${ }^{11}$ По другим данным, количество советских военнопленных, содержавшихся в шталагах ОКВ и аффилиированных с ними рабочих командах, было ощутимо выше: в частности, 1680287 по состоянию на 1 января 1945 г. [Россия и СССР... 2001: 460]. Со ссылками, в том числе, на трофейные документы: ЦАМО. Ф.500. ОП. 1245. Д.86.

12 Согласно советским данным, в добровольческих соединениях, составленных из представителей различных народов СССР, включая полицейские и вспомогательные формирования, в середине июля 1944 г. насчитывалось более 800 тыс. человек [Гриф секретности снят... 1993: 385]. Сюда, очевидно, включены и добровольцы из числа гражданских лиц.

${ }^{13}$ По данным А. Даллина погибло еще больше - 3,7 млн человек или 63\%. Генеральный прокурор СССР Р.А. Руденко обнародовал цифру советских военнопленных, замученных и истребленных на оккупированной территории: 3912283 человек - Правда(1969).
} 
г., у генерала Власова и в других коллаборантских (в том числе небоевых) соединениях служили, вероятно, около 1 млн человек, еще около 0,4 млн успешно бежали из лагерей или были освобождены Красной Армией.

С учетом того, что на территории ОКХ весной 1944 г. их практически не было, суммарное число военнопленных, депортированных за довоенные границы СССР, можно оценить приблизительно в 3,25 млн человек. Выявить среди них число тех, кто находился непосредственно в Рейхе, практически невозможно. Но, с учетом данных об умерших и о репатриированных военнопленных, мы можем оценить их величину приблизительно в 2,12,2 млн человек.

\section{СОВЕТСКИЕ ВОЕННОПЛЕННЫЕ-ЕВРЕИ: ОБРЕЧЕННЫЕ ПОГИБНУТЬ}

Гитлер сумел выстроить несколько простых и оказавшихся вполне доступными немецкому народу и хорошо им усвоенными иерархий. Кроме расовой табели о рангах, где евреи занимали самую низкую ступень, помимо идеологической шкалы степеней угрозы для Рейха и соответствующей встречной ненависти, где выше всех стояли «жидобольшевистская интеллигенция» и «политические комиссары» как носители коммунистической идеологии, своя иерархия была и у военнопленных: из всех армий многочисленных противников Рейха ниже всех «котировались» советские военнопленные ${ }^{14}$.

Так что же тогда говорить о советских военнопленных еврейского происхождения, да еще и политруках! Что может быть ниже, хуже и ненавистнее?!..

Согласно сведениям, опубликованным Ф.Д. Свердловым [2002: 214] ${ }^{15}$, в Красной Армии в 1941-1945 гг. находилось 450-470 тыс. евреев, что составляло примерно 1,7\% от общей численности вооруженных сил СССР и $16 \%$ всего еврейского населения СССР. Интересно, что 27\% евреев ушло на фронт добровольно, 80\% евреев-красноармейцев служило в боевых частях [Шапиро, Авербух 1997: 448, 466-477].

Исходя из той же доли, число погибших евреев должно было бы составить порядка 205 тыс. человек ${ }^{16}$. Данные ЦАМО лишь незначительно отличаются от этой цифры - 198 тыс. погибших в бою, умерших от ран и болезней или пропавших без вести [Шнеер 2003

\footnotetext{
${ }^{14} \mathrm{O}$ геноциидальном характере политики Германии по отношению к советским военнопленным как к контингенту в целом см. прежде всего в: [Streit 1991; Полян 1996; 2002; 2006; Gerlach 1999; Шнеер 2003; Polyan 2005]. Эта политика была дифференцированной в этническом плане (так, украинцы, белорусы, грузины, представители северокавказских народностей, не говоря уже о фольксдойче, были привилегированны в целом ряде отношений - см. ниже), но предпринятая К. Беркофом попытка придать этой политике в целом еще и этноциидальный - направленный на русских как этнос - характер [Berkoff 2001] не представляется нам убедительной. Единственным этносом в составе красноармейцев, уничтожавшемся поголовно, были евреи (сведениями о селекции и уничтожении военнослужащих-цыган мы не располагаем).

${ }^{15}$ Без учета еще нескольких сот человек, призванных на военную службу, начиная с сентября 1944 г., в армии Румынии и Болгарии (источник сведений, к сожалению, не указан). В другом месте тот же Ф.Д. Свердлов называет цифру в 450-470 тыс. евреев в Красной Армии; ее же повторяет и А. Арад [Шнеер 2003 Т.2: 28 ].

${ }^{16}$ Ф.Д. Свердлов приводит иную цифру погибших в боях - 150 тыс. человек. В 200 тыс. человек он оценивает боевые потери евреев-военнослужащих в целом [Свердлов 2002: 214].
} 
T.2: 29]. ${ }^{17}$ Звания Героя Советского Союза был удостоен 131 еврей, из них 45 посмертно [Марьяновский, Соболь 1997: 14-15] ${ }^{18}$.

С первых же часов войны Третий Рейх не оставлял евреев без своего смертоносного «внимания». Первые убийства советских военнопленных-политкомиссаров (и среди них евреев) датируются, буквально начиная с 22 июня 1941 г.!

А это означает следующее. Во-первых, первыми по времени палачами военнослужащих-евреев в геноциидальной германо-советской войне стали военнослужащие вермахта. Во-вторых, их первыми еврейскими жертвами де-факто в этой войне стали советские военнопленные-евреи, а первыми жертвами де-юре - евреиполитработники.

Число советских евреев в немецком плену, по оценке Ш. Краковского, составляло около 85 тыс. человек [Krakowski 1992: 229]. Практически ту же цифру - 80-85 тыс. - вслед за ним называет И. Арад [Arad 1993: 125]. При этом исследователи отталкивались от 1,8\%ной доли евреев в населении СССР, что, если и искажает данный расчет, то в сторону завышения.

Самым высокопоставленным среди них, возможно, являлся генерал-майор интендантской службы Григорий Моисеевич Зусманович, раненый и взятый немцами в плен 24 мая 1942 г. под Харьковом [Свердлов 2002: 342-344] ${ }^{19}$.

Всего же, по имеющимся оценкам, гитлеровцы уничтожили от 70 тыс. (И. Арад ${ }^{20}$ ) до 80 тыс. [Шнеер 2003: 91] советских евреев-военнопленных. Вторая оценка, соответствующая 94\%-ной смертности евреев в немецком плену, представляется нам более реалистичной. Во-первых, в ее пользу свидетельствует число евреев-военнопленных среди репатриированных в СССР (около 5 тыс. человек).

Если же придерживаться оценки А. Шнеера и вспомнить, что во время войны погибло порядка 200 тыс. евреев-красноармейцев, то доля погибших в плену среди них составила $40 \%$.

В литературе встречаются и некоторые частичные оценки смертности среди военнопленных-евреев. Так, по состоянию на 21 декабря 1941 г., согласно отчету шефа гестапо Мюллера, было выявлено около 22 тыс. неблагонадежных советских военнопленных, из них 16 тыс. уничтожено: «квота» евреев среди уничтоженных предположительно была не ниже 90\%, так что порядка 14-15 тыс. еврейских военнопленных было ликвидировано только за это время и, судя по полномочиям Г. Мюллера, только в зоне ответственности ОКВ [Hilberg 1999: 357]. К середине 1942 г.

\footnotetext{
17 Это соответствует около 40\% общих безвозвратных потерь (против 25\% по Красной Армии в целом) [Шнеер 2003 T.2] .

18 По этому показателю евреи занимают третье место вслед за русскими и украинцами при том, что по численности населения они были накануне войны лишь седьмыми. См. также [Шнеер 2003 Т.2: 41 -42].

${ }^{19}$ Г.М. Зусманович (1899-1944) был заместителем командующего 6-й армии по тылу (командарм - генераллейтенант И.Н. Музыченко). Как и многие другие, Зусманович скрывал свою национальность, выдавая себя за украинца и говоря с немцами только по-украински. Был в лагерях в Холме, Нюрнберге, с 1943 г. - в Вайсенбурге, где осенью 1944 г. умер.

${ }^{20}$ Устное сообщение в ноябре 2004 г. в Иерусалиме.
} 
число неблагонадежных советских военнопленных, выявленных на той же территории и переданных СС, достигло, по оценке Р. Отто, не менее 40 тыс. человек [Otto 2002: 133]. Квота евреев среди них не могла не понизиться (среди выявленных было немало саботажников, беглецов и т.д.), да и среди отправленных в концлагеря погибали, разумеется, не все, - тем не менее, суммарная оценка числа евреев среди них по меньшей мере в 25 тыс. человек представлялась бы вполне реалистичной. В таком случае на зону ответственности ОКХ приходится около 55 тыс. убитых советских евреев-военнопленных.

Их селекции и расстрелы начались, как мы уже отмечали, буквально на следующий день после нападения на СССР. Свидетельства при этом оставили как немецкие палачи, но и нееврейские очевидцы, а также сами чудом уцелевшие жертвы.

Обработка данных об умерших советских офицерах-военнопленных из трофейной картотеки в ЦАМО показала, что более трети из них - военные врачи, ветеринары или фельдшеры, немногим меньше - техников-интендантов и инженеров, строевых же офицеров - около 20\%. Разброс по возрасту (на 1941 г.) - от 21 года до 50 лет. Около 2/3 уроженцы Украины, остальные родом из России и Прибалтики. Почти 80\% попали в плен на Украине в 1941 г., из них в одном только сентябре - 60\% ${ }^{21}$ [Марьяновский, Соболь 1997: 33]! 10 человек попали в плен в 1942 г., а самым «поздним» по времени пленения оказался капитан Б.Г. Зарин, захваченный 25 сентября 1944 г. и выведенный из состояния плена 11 ноября того же года (для отправки в концлагерь, надо полагать).

Около 2/3 из них простились с жизнью в дулагах или шталагах на оккупированной территории, остальные - в шталагах и концлагерях в Германии. Несколько лагерей встречаются особенно часто - это шталаги 346 (Кременчуг) и 334 (Белая Церковь), концлагерь Заксенхаузен и шталаг IIIВ Фюрстенберг. Лишь в 10\% случаев военнопленные умерли своей смертью, например, от бомбежки или в больнице. Во всех остальных случаях они были переданы дальше для ликвидации либо СД (если дело происходило в оперативной зоне на оккупированной территории СССР), либо гестапо и СС (в зоне ответственности ОКВ) или же застрелены при попытке к бегству. Карточки 10 военнопленных однозначно запечатлели следы селекции или доноса: названная ими самими и принятая немцами к сведению национальность - украинец, русский, белорус или азербайджанец - исправлена на них красным карандашом на «еврей». На удивление много карточек (более половины), где в графе национальность «еврей» стоит с самого начала. Однако самой продолжительной (более 3 лет) жизнью в плену отмечен лейтенант и автомеханик Иосиф Базаненко, назвавшийся русским: взятый в плен 22 сентября 1941 г. под Оршицей и угнанный в шталаг XIII D в Нюрнберге, он был убит при авианалете 19 октября 1944 г.

Тем не менее части евреев удалось скрыть свою подлинную национальность и свое подлинное имя, а если им и дальше везло, то и уцелеть даже на территории врага. Ведь только по официальным данным Управления по делам репатриации при Совете Министров СССР среди репатриированных после войны граждан СССР насчитывалось 11428 евреев,

\footnotetext{
${ }^{21}$ Возможно, это связано с массовой отправкой в это время на фронт необученных евреев-добровольцев. Для сравнения: из 23 бывших советских военнопленных-евреев, зарегистрированных при Московской Ассоциации узников фашистских концлагерей, 14 попали в плен в 1941 г., по 2 - в 1942 и 1943 г. и 4 - в 1944 1945 гг.
} 
из них 6666 гражданских лиц и 4762 военнопленных, в том числе даже среди контингента «власовцы» - более сотни человек [Полян 1996: 298, 312]! Учитывая и тех, кто и при репатриации, на всякий случай, не выдал своего еврейства, общее число евреев среди репатриированных могло составить приблизительно 15 тыс. человек, причем пропорция могла измениться только в пользу остарбайтеров, поскольку военнопленных фильтровали неизмеримо тщательнее, чем гражданских лиц.

\section{СОВЕТСКИЕ ВОЕННОПЛЕННЫЕ ВНЕ КОМПЕТЕНЦИИ ТРЕТЬЕГО РЕЙХА}

Из союзных Германии стран только Финляндия и Румыния держали на своей территории и даже эксплуатировали труд советских военнопленных.

Так, согласно официальным финским данным, в 1941-1944 гг. финны взяли в плен 64188 советских солдат и офицеров. Из них погибло в плену 19016 (или 29,6\%), бежало из плена 712 (1,1\%), передано немцам 2048 (3,2\%), репатриировано в СССР 42412 (66,1\%) [Дугас, Черон 1994: 59] ${ }^{22}$.

В книге «Жертвы двух диктатур» (как в первом, так и во втором изданиях) я писал о том, что не располагал сведениями о советских военнопленных в румынском плену, аналогичными тем, которые имеются по советским военнопленным в финском плену. Отталкиваясь от числа репатриированных военнопленных и при допущении в условиях Румынии того же уровня смертности, что и в Финляндии, общее число военнопленных в Румынии составляло бы не менее 40 тыс. человек [Полян 2002:130].

Знакомство с румынскими архивными и литературными военно-историческими источниками позволяет основательно скорректировать эту оценку.

Румыния объявила войну СССР 22 июня 1941 г., а масштабные наступательные действия начала 2 июля, т.е. ровно в тот самый день, когда, по версии В. Суворова, СССР планировал ударить по Румынии. В боях на советско-германском фронте принимали участие 11-я немецкая и 3-я и 4-я румынские армии, стратегически и оперативно подчиненные вермахту - командованию немецких армий группы «Юг».

Тем не менее отсчет первым советским военнопленным в румынском плену ведется еще с 26 июня 1941 г., но это исключительно дезертиры и перебежчики, подавляющее большинство которых составляли этнические молдаване. Что же касается военнопленных, захваченных, что называется, с бою, то их по сравнению с немецкими показателями было не так уж и много. За два месяца боев за Одессу 4-я румынская армия взяла в плен около 16 тыс. человек, а 3-я армия к лету 1942 г. - не менее 87 тыс. красноармейцев. По оценке М. Эксворти, общее число пленных, захваченных румынами, не превышало 120 тыс. человек [Axworthy 1995: 71, 217].

Согласно энциклопедическому словарю «Румынская армия во Второй мировой войне (1941-1945)», выпущенному в Бухаресте в 1999 г. [Dutu, Dobre, Loghin 1999: 329-

22 Со ссылкой на [Roschmann 1982]. По советским данным, число репатриированных военнопленных практически совпадает: 42778 человек (см. [Полян 2002: Табл. 5.6.1]). 
$341]^{23}$, за период между 22 июня 1941 и 23 августа 1944 г. $^{24}$, т.е. за время боевых действий между советской и румынской армиями, румыны взяли в плен 91060 советских военнослужащих ${ }^{25}$.

Военнопленные поступали из зоны действия румынской армии, в частности, 21 тыс. прибыла из Транснистрии и 19 тыс. - из Крыма. Около 2 тыс. военнопленных было на судне, потопленном советской подлодкой в районе Бургаса, и лишь 170 из них спаслись.

Из 91060 советских военнопленных 13682 было отпущено из плена (румыны, - а скорее всего румыны и молдаване - из Северной Буковины и Бессарабии; немцыфольксдойче передавались немецкой стороне и скорее всего не регистрировались), 82057 было доставлено в Румынию, 3331 бежали и 5223 (или 5,7\%) умерли в лагерях. Если эта статистика не сфальсифицирована, то это на порядок меньшая величина по сравнению со смертностью советских военнопленных в финском и, особенно, в немецком плену. Из 5223 умерших - всего лишь 55 офицеров и 6 младших офицеров. Остальные - солдаты, причем больше всего умерло в Будешти (938 человек), Вулкане (841), Васлуе (799) и Фельдоаре (738). Главная причина смертности - туберкулез (1100 человек). Убито или расстреляно всего 30 человек плюс одно самоубийство. К 23 августа 1944 г. в румынских лагерях находилось 59856 человек [Axworthy 1995].

Для советских военнопленных было создано 12 лагерей, из них два лагеря находились вне Румынии - в Тирасполе и Одессе. В самой Румынии находилось, по утверждению румынских историков, 10 лагерей, однако сам перечень лагерей, хотя бы раз упоминаемых в их тексте, несколько превосходит это число ${ }^{26}$.

Небольшая коллекция, посвященная советским военнопленным в Румынии, имеется в РГВА. Это фонд 1512 «Румынские концлагеря для советских военнопленных», состоящий из одной описи и 40 единиц хранения. Материалы, датированные временем с 1941 по 1944 г., охватывают следующие 12 румынских «шталагов», список которых несколько отличается от сети, описанной румынскими историками:

1. лагерь военнопленных №1. Слободзия-Ялоница (дд.1-3);

2. лагерь военнопленных №2. Фельдиора-Брашов (дд.4-5);

3. лагерь военнопленных №3 Галац (лагерь «Индепенденца», или «Независимость») (дд.6-9);

4. лагерь военнопленных №4. Васлуй (дд.10-11);

5. лагерь военнопленных №5. Тирасполь (Бессарабия) (дд.12-14);

6. лагерь военнопленных №6. Дорнешты (дд.15-16);

7. лагерь военнопленных №7. Бельун (Бессарабия) (дд.17-18);

8. лагерь военнопленных №8. Болград (Бессарабия) (дд.19-20);

9. лагерь военнопленных №9. Вулкан (дд.21-22);

${ }^{23}$ Сведения без указания источника в данном подразделе восходят к этой публикации.

24 Дата антифашистского восстания в Румынии, приведшего к свержению режима Антонеску и объявлению войны Германии.

${ }^{25}$ Для сравнения: англо-американских пленников было 1100 человек.

${ }^{26}$ А именно: Слободзия, Владень, Брашов, Абаджеш, Корбень, Карагунешт, Дева + Индепенденца, Ковулуй

+ Майя, Васлуй, Дорнешти, Радоуть, Будешти, Фельдиора, Боград и Ригнет. 
10. лагерь военнопленных №10. Александрия (дд.23-24);

11. лагерь военнопленных №11. Тирасполь (Бессарабия) (дд.25-26);

12. лагерь военнопленных №12. Тимишоара (дд.27-28).

Большинство документов этих дел - личные листки советских военнопленных, но один раз (в д.12) встречаются и списки военнопленных, использовавшихся на различных работах.

Отвечало за военнопленных Управление вооруженных сил внутренней обороны под командованием генерала Харитона Драгомиреску. Сами лагеря охранялись румынской жандармерией, численный состав которой по состоянию на 1 августа 1942 г. был 5210 человек (216 офицеров, 197 унтер-офицеров и 3797 солдат).

Условия жизни в лагерях в соответствии с международным правом существенно разнились для офицеров и солдат: первые жили в каменных домах, вторые - в деревянных бараках, а осенью 1941 г. - частично в землянках, под открытым небом (печи для бараков поступили только в 1942 г.). Лагеря для советских военнопленных обслуживало более 150 врачей: 6 румынских, 66 еврейских и 85 советских.

В партизанских отрядах в Польше, Чехословакии, Югославии, Италии и Франции сражалось, по неполным данным, более 40 тыс. советских граждан, подавляющее большинство среди которых - советские военнопленные [Семиряга 1970: 7] ${ }^{27}$. Таким образом, за границей СССР, но вне компетенции или досягаемости органов Рейха, находилось не менее 190-195 тыс. советских военнопленных.

\section{СОВЕТСКИЕ ВОЕННОПЛЕННЫЕ - РЕПАТРИАНТЫ}

Общее число советских граждан, пересекших в 1941-1944 гг. (и не по своей, а по немецкой воле) довоенную государственную границу СССР, составляло, по нашей оценке, около 8,7 млн человек [Полян 2002: 135]. Распределение этого огромного контингента по указанным категориям представляется следующим (таблица 3 ).

Таблица 3. Лица, до войны проживавшие на территории СССР и перемещенные во время войны за границу*

\begin{tabular}{l|l|c|c}
\hline \multicolumn{1}{c}{ Кo } & \multicolumn{1}{c|}{ Категория } & Млн человек & В \% к итогу \\
\hline I & Гражданские интернированные & 0,005 & 0,0 \\
II & Военнопленные & 3,24 & 37,2 \\
III & Остовцы (остарбайтеры-”восточники”) & 3,2 & 36,8 \\
IV & “Западники” & 0,85 & 9,8 \\
V & Фольксдойче & 0,35 & 4,0 \\
VI & Финны-ингерманландцы & 0,06 & 0,7 \\
VII & «Беженцы» & 1,0 & 11,5 \\
VIII & «Эвакуированные» & & \\
& Всего & 8,7 & 100,0 \\
\cline { 2 - 4 }
\end{tabular}

Примечание: * - На территорию Германии, ее союзников или оккупированных ими стран.

27 В Италии, например, сражалось 5600, во Франции около 3000, в Бельгии 800 человек [Советские люди...1991: 5]. 
Как ни скудны исходные данные, но все же затронем вопрос и о распределении советских граждан по времени их депортации в Германию (таблица 4).

Таблица 4. Распределение бывших советских военнопленных по состоянию на 1 марта 1946 г. по годам их пленения, \%

\begin{tabular}{l|r}
\hline Год пленения & $\%$ \\
\hline 1941 & 47,9 \\
1942 & 33,1 \\
1943 & 12,2 \\
1944 & 5,3 \\
1945 & 1,5 \\
Итого & 100,0 \\
\hline
\end{tabular}

Источник: Рассчитано по ГАРФ. Ф.Р-9526. Оп.1. Д.1. Л.227 (данные неполные).

Почти половина доживших до конца войны и затем репатриировавшихся советских военнопленных относится к 1941 г. пленения, еще треть - к 1942 г.

Интересно сравнить данные по репатриации военнопленных с данными А. Даллина о хронологической структуре собственно пленения. Оказалось, что из числа плененных в гиблом и роковом 1941 г. репатриации дождалось только 22,4\%, в 1942 г. - 31,4\%, в 1943 г. - 33,9\%, в 1944 г. - 56,3\% и в 1945 г. - 67,6\%. Для всей же совокупности советских военнопленных этот показатель составил $27,3 \%$. Остальное, стало быть, либо погибли (и таких решительное большинство), либо остались на Западе.

Рассчитывая для таблицы 5 предложенный нами «индекс дожития» военнопленных, мы использовали смесь упомянутых немецких и советских данных ${ }^{28}$.

Таблица 5. Распределение советских военнопленных и репатриантов из военнопленных по годам пленения

\begin{tabular}{|c|c|c|c|c|c|}
\hline \multirow{2}{*}{$\begin{array}{l}\text { Год } \\
\text { пленения }\end{array}$} & \multicolumn{2}{|c|}{ Тыс. человек } & \multicolumn{2}{|c|}{ В \% к итогу } & \multirow{2}{*}{$\begin{array}{c}\text { Индекс } \\
\text { дожития } \\
(\text { Б) } /(\mathrm{A})\end{array}$} \\
\hline & $\begin{array}{c}\text { попавшие в плен } \\
\text { (A) }\end{array}$ & $\begin{array}{c}\text { репатриированные } \\
\text { (Б) }\end{array}$ & $\begin{array}{c}\text { попавшие в } \\
\text { плен } \\
\end{array}$ & репатриированные & \\
\hline 1941 & 3355 & 673 & 58,3 & 49,2 & 0,20 \\
\hline 1942 & 1653 & 449 & 28,7 & 32,8 & 0,27 \\
\hline 1943 & 565 & 160 & 9,8 & 11,6 & 0,28 \\
\hline 1944 & 147 & 70 & 2,6 & 5,1 & 0,48 \\
\hline 1945 & 34 & 18 & 0,6 & 1,3 & 0,53 \\
\hline Всего & 5754 & 1370 & 100,0 & 100,0 & 0,24 \\
\hline
\end{tabular}

Источник: Рассчитано по [Dallin 1958: 440]; ГАРФ. Ф.9526. On.1. Д.1. Л. 227.

Более 3/5 военнопленных были захвачены врагом в 1941 г., из них репатриации дождался только каждый пятый. Но пленных за 1941 г. было так много, что и в репатриационном потоке их почти половина. Низкой доживаемостью $(0,27-0,28)$ характеризуются и 1942, и 1943 г., и лишь из плененных в 1944-1945 гг. (а это в общей сложности лишь около 180 тыс. человек) репатриации дождался почти каждый второй военнопленный.

\footnotetext{
${ }^{28}$ К очевидным дефектам этого показателя, помимо неоднородности использованной статистики, относится также вынужденный «зачет» не репатриировавшихся в умершие.
} 


\section{ПРИНУДИТЕЛЬНАЯ РЕПАТРИАЦИЯ БЫВШИХ СОВЕТСКИХ ВОЕННОПЛЕННЫХ}

С учетом «внутренних перемещенных лиц» ${ }^{29}$ органы репатриации возвратили в СССР в течение 1944 г. 1050398, а в течение 1945 г. -4514201 советских граждан ${ }^{30}$. По существу, их массовая репатриация фактически закончилась уже в сентябре-октябре 1945 г.

С каждым следующим годом поток репатриантов все более и более мельчал. Если в 1946 г. их число составило солидную цифру в 195273 человек, то в 1947 г. - всего 30346 человек или вшестеро меньше. В 1948 и 1949 г. - почти двукратные сокращения: соответственно 14272 и 6542 человек; в 1950 г. -4527 и в 1951 г. -2297 репатриантов ${ }^{31}$. Итого за 1946-1951 гг. 253239 человек, большая часть из которых, впрочем, возвращена из оккупационных зон СССР и из восточноевропейских стран.

Необходимо указать на принудительный характер советской репатриации. Она была принудительной вовсе не потому, что люди не хотели возвращаться на родину, а их палками заставляли. Большинство как раз хотело домой, невзирая на все связанные с этим риски. Принудительной она была потому, что никого в СССР даже не интересовало, хочет кто-то домой или не хочет: все советские граждане, согласно Ялтинским соглашениям, были обязаны это сделать и именно потому, что они советские граждане.

Таблица 6. Накопленные числа бывших советских военнопленных, репатриированных в СССР в 1944-1945 гг., чел.

\begin{tabular}{l|c|c}
\hline Дата & Освобожденные и зарегистрированные, всего & В том числе репатриированные \\
\hline 31.10 .1944 & 87814 & 30906 \\
10.11 .1944 & 151832 & 50935 \\
10.12 .1944 & 245036 & 82864 \\
30.12 .1944 & 506167 & 343349 \\
01.05 .1945 & 683394 & 475684 \\
20.06 .1945 & 1574920 & 840994 \\
01.08 .1945 & 2037395 & 1599613 \\
01.09 .1945 & 1985224 & 1804316 \\
01.11 .1945 & 2106416 & 1811816 \\
01.12 .1945 & 2016460 & 1815022 \\
\hline
\end{tabular}

Источники: За 1944 г. - РГАНИ. Ф. 89. Оп.40. Д.4. Л.1-14; за 1945 г. - ЦАМО. Ф.40. Оп.11549. Д.265. Л.11, 25, 110, 188, 219, 237, 253, 260, 311, 317, 325.

Примечание: Bпервые опубликовано [Overmans, Hilger, Polian 2012: 866].

Вычленить советских военнопленных в общем потоке репатриантов непросто, в таблице 6 представлены соответствующие сводные результаты. Для миллионов советских граждан, попавших под германский каблук, было глубоко не безразлично, где их застигло долгожданное освобождение: в пределах ли СССР или за границей, а если за границей и на территории бывшего Рейха, то в какой его части: восточной, подконтрольной «своим», или

\footnotetext{
29 Освобожденных внутри границ СССР.

${ }^{30}$ Сводка №74 о репатриации советских и иностранных граждан, по состоянию на 1.1.1949: АВП.Ф.082. ОП.36. П.185. Д.23. Л.1-4.

${ }^{31}$ ГАРФ. Ф.Р-9526. Оп.1. Д.7. Л.3.
} 
же западной, т.е. «союзнической». Имеющиеся в нашем распоряжении данные мы свели в таблицу 7.

Таблица 7. Структура потока репатриантов в СССР по состоянию на 1 марта 1946 г.

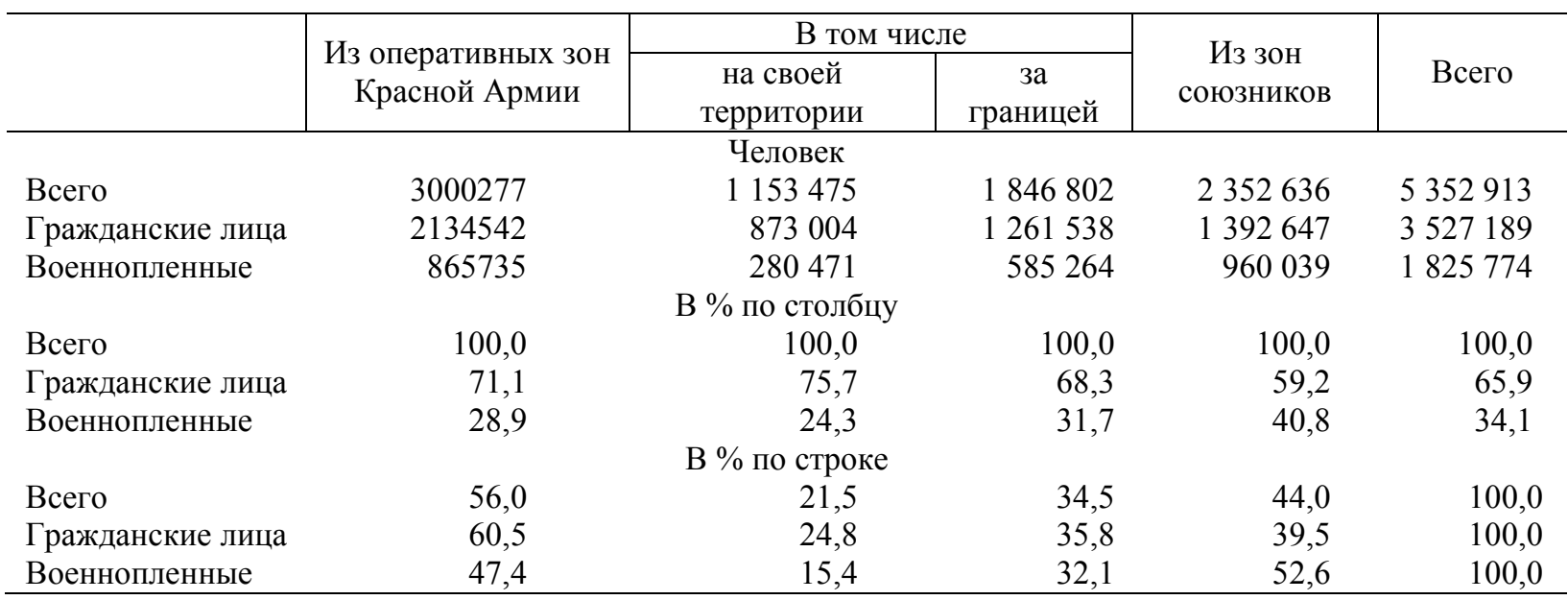

Источник: ГАРФ. Ф.9526. Оп.1. Д.1. Л.227.

С учетом невозвращенцев, приблизительно $3 / 5$ советских людей, занесенных войной в бывший Рейх, оказалась в его западных частях, оккупированных Англией и США. Тем не менее (из-за тех же “невозвращенцев”) 56\% возвращенных в СССР граждан были освобождены Красной Армией.

Попытка экспертного суммирующего демографического баланса принудительных депортаций граждан СССР в Германию и их репатриации осуществлена в таблице 8.

Фильтрация же репатриантов показала, что в распоряжение НКВД, т.е. в спецконтингент, поступили 6-7\% репатриированных (а это порядка 300 тыс. человек!), из них большинство военнопленные. Среди них были и те, кого судили и осудили в экстазе сверхподозрительности (в предательстве априори подозревали каждого; а к советским военнопленным-евреям смершевцы могли себе позволить обратиться с вопросом: «И как это ты, Абрам, жив остался?..»). Но среди осужденных было немало и тех, кто действительно нарушил присягу и, став предателем, совершил военные преступления (немало таких предателей было и среди айнзатцкомманд и айнзатцгрупп СД, специализированных на ликвидации коммунистов, евреев, цыган, душевнобольных и некоторых других категорий лиц).

Таблица 8. Лица, проживавшие до войны на территории СССР и оказавшиеся во время войны на территории Германии и союзных ей стран, по отношению к репатриации в СССР*

\begin{tabular}{l|l|r|r}
\hline & \multicolumn{1}{c|}{ Категория } & Млн человек & \multicolumn{1}{c}{$\%$} \\
\hline & Всего & 8,7 & 100,0 \\
& в том числе: & & \\
А & умерли или убиты & 2,1 & 24,1 \\
Б & репатриированы немцами (“возвратники”) & 0,15 & 1,7 \\
В & саморепатриировались & 0,4 & 4,6 \\
$\Gamma$ & репатриированы государством & 5,35 & 61,5 \\
Д & уклонились от репатриации (“невозвращенцы”) & 0,7 & 8,1 \\
\hline
\end{tabular}


В то время понятий «коллаборанты» или «коллаборационисты» как таковых еще не существовало. Их аналогом было понятие «власовцы», трактуемое крайне широко и отнюдь не сводящееся к военнослужащим РОА, успевших присягнуть и Сталину, и Гитлеру. Как правило, они получали по шесть лет, и с ними как с априори предателями не церемонились и не цацкались (для отбытия наказания их, как правило, отправляли на Колыму). Отдельные коллаборанты из числа бывших советских военнопленных, такие как сам генерал Власов, атаман Доманов или же члены соединений СС или СД, были казнены.

Остальных же бывших военнопленных после фильтрации или демобилизовывали и отпускали домой (рядовыми в запризывном возрасте), или, наоборот, вновь призывали в армию (и некоторые из них успели даже немного повоевать - с Германией или с Японией; разновидностью этого стала работа в советских репатриационных и демонтажных миссиях в советских оккупационных зонах и Польше). Весьма распространенной вариацией судьбы военнопленного-репатрианта была мобилизация в трудовые батальоны Наркомата обороны - формально добровольная, а по сути (и по режиму содержания) столь же насильственная и репрессивная.

Но все-таки надо четко сказать: расхожее представление о репатриации советских граждан, в том числе и бывших военнопленных, как о почти поголовной репрессии и передаче их в ГУЛАГ не соответствует действительности. Это один из мифов холодной войны, вспыхнувшей между вчерашними союзниками вскоре после их общей и безоговорочной победы над общим врагом [Полян 2002: 526-543].

Таким же мифом-«страшилкой» являлись и рассказы о поголовных - под звуки ревущих двигателей, мужских хоров или других глушителей - расстрелах без суда и следствия членов коллаборантских соединений, передававшихся англичанами и американцами в союзнические советские руки в буквальном соответствии с Ялтинскими соглашениями (и иногда и без такого соответствия). Другое дело, что бывшие военнопленные действительно и довольно массово пополняли собой контингент ГУЛАГа, но происходило это уже вне всякой связи с репатриацией.

Очень многих из них СМЕРШ и ведомство Филиппа Голикова (Управление по делам репатриации при Совмине СССР) после войны передавали вместе с картотеками на контроль и дальнейшую пастьбу в руки МВД или МГБ. Эти органы держали бывших военнопленных на коротком поводке и на своеобразном крючке, следя за ними, вызывая для бесед, вербуя в ряды своих осведомителей.

В зависимости от их реакции, от кагэбэшных разнарядок и от конъюнктуры «рынка» лагерного труда, у тех репатриантов, кто уже худо-бедно интегрировался в новую послевоенную жизнь страны, шансы загреметь в ГУЛАГ могли резко возрасти. Еще выше они были у тех бывших военнопленных, кто уже отсидел небольшие сроки. Так что конец 1940-х и начало 1950-х годов - это время пусть и индивидуальных, но ощутимо массовых посадок, а отмена смертной казни дала необычайный прирост средней продолжительности присуждаемых сроков. 
Передо мной не опубликованные еще воспоминания москвича Анатолия Баканичева, 1920 г. рождения, одного из таких «героев» ${ }^{32}$. Летом 1939 г. он поступил на биофак МГУ, и его тут же призвали в Красную Армию. Горьковские, Гороховецкие лагеря, переброски по направлению Прибалтики и Молдавии и, наконец, марш-бросок в Лиду, завершившийся буквально 21 июня 1941 г. В последующие дни - окружение, попытки из него вырваться и 6 июля - попадание в плен, вереница лагерей, из которых последним (и рабочим) был лагерь Штайерберг под Ганновером. В тех местах он и встретил свое освобождение из плена американцами.

Потом советская репатриационная миссия, Берлин, Ной-Руппин, фильтрация, на которой в качестве станции назначения он назвал Можайск (Москва была для него закрыта). Немного схитрив, он саморепатриировался - и до Москвы. Прописался он с большим скрипом, поступил сначала в Губкинский нефтяной, а потом в Тимирязевский сельскохозяйственный вузы, но от лестных предложений сотрудничать с органами упорно отказывался.

В итоге 19 февраля 1948 г. он был арестован и получил 15 лет каторжных работ (были недолгое время и такие в эти годы) «за избиение военнопленного С. во время нахождения в плену»! (Суров закон, не правда ли?) Отбывать начал в Норильске, в одном из горлагов. Предпринял попытку побега, правда, неудачную.

И освободился только в 1956 г., по хрущевской амнистии.

\section{ПЕРЕМЕНЫ ТЯЖЕЛОГО, ИЛИ ДЕМИФОЛОГИЗАЦИЯ}

Реальный же итог принудительной репатриации - это на всю оставшуюся жизнь большая черная клякса в анкете и отчетливая дискредитация в повседневной жизни и на карьерных траекториях (единичные исключения были, но погоды не делали). Добавим сюда и повышенный риск быть арестованным!

В этом и только в этом смысле - в плане их социальный второсортности справедливо говорить о бывших военнопленных как о жертвах не только немецкой, но и советской диктатуры. Но в таком случае лукавят и подличают те, кто утверждают: судьба советских репатриантов на родине - такая же, как и остальных граждан Союза.

Сладко не было тогда никому, но даже в бесправовом обществе есть свои «перемены тяжелого», как говорил Виталий Семин, и свои ступени бесправия.

Репатрианты и бывшие военнопленные - это граждане второго сорта. Они это пережили и это знают, для них это не миф, а жизненный фон, жизненные опыт и правда.

Первая тому иллюстрация - продолжающаяся апология практики и теории репатриации по-советски! Свое отражение она нашла в работах В. Земскова, А. Шевякова и Ю. Арзамаскина [Земсков 1993; Шевяков 1994; Арзамаскин 1999], несших, наряду с

32 Архив общества «Мемориал». Ф.2. Оп.1. Д. 4. 
эмпирической, и идеологическую нагрузку. Так, В. Земсков в статье 1993 года с особенным рвением взялся за трудную работу по «демифологизации» репатриации советских граждан.

Но и большинство западных суждений и оценок столь же мало опираются на специальные исследования и столь же политизированы, как и советские. Так, общим местом, например, был тезис о чуть ли не поголовном нежелании возвращаться в СССР украинцев или жителей Прибалтики, или об их же поголовной отправке в лагеря.

Ни бывшие советские военнопленные, ни бывшие окруженцы явно не в фаворе и даже не в визире у Советского (Российского) комитета ветеранов войны или у Российского организационного комитета «Победа» ${ }^{33}$. Впрочем, и сами ветераны Великой отечественной войны внутри общеветеранского движения все заметнее вытесняются и задвигаются на задворки ветеранами боевых действий последующих десятилетий, - горькая, но закономерная (по крайней мере, демографически) действительность. Но никакого демографического оправдания не было и нет той горькой несправедливости, которую сами бывшие фронтовики - ветераны войны учиняли и учиняют по отношению к своим ровесникам и сотоварищам по оружию, имевшим на ратном пути несчастье оказаться во вражеском плену или окружении. В ветеранской среде бывших военнопленных всегда только игнорировали и дискриминировали.

Когда накануне 50-летия Победы первый президент РФ Б.Н. Ельцин 24 января 1995 г. издал Указ №63 «О восстановлении законных прав российских граждан - бывших советских военнопленных и гражданских лиц, репатриированных в период Великой Отечественной войны и в послевоенный период» ${ }^{34}$, он едва ли не впервые после Нюрнбергского трибунала признал бывших советских военнопленных не только участниками войны, но еще и жертвами нацизма.

Но даже этот на десятилетия опоздавший указ вызвал далеко не однозначные отклики. Весьма показательна, хотя и поразительна, реакция со стороны тех, кого миновал плен: «В широкой ветеранской общественности», - сообщал корреспонденту «Российских вестей» зам. председателя Российского совета ветеранов войны, труда, Вооруженных сил и правоохранительных органов В. Смирнов, - «[указ] в цеелом воспринят положительно», но при этом «есть и будут неоднозначные оценки среди бывших фронтовиков уравнивания в правах и льготах тех, кто, например, прошагал дорогами войны от Москвы до Берлина, и находившихся, пусть и не по своей вине, в немеиком плену» [Советские военнопленные... 1995].

Тут до боли узнаваемы и «лексика», и «принципиальность». По-прежнему свысока и презрительно взирают прошагавшие от Москвы до Берлина на тех, кому на пути от Бреста до Москвы пришлось под конвоем завернуть в шталаг. К этому, процеженному сквозь зубы

\footnotetext{
33 Они даже ни разу не упомянуты ни в одном (!) из документов последнего, оказавшихся доступными пишущему эти строки.

34 Согласно пункту 5 Указа, его действие не распространяется на бывших советских военнопленных и гражданских лиц, служивших в строевых и специальных формированиях немецко-фашистских войск, полиции и иных лиц, не подлежащих реабилитации согласно Закону РФ «О реабилитации жертв политических репрессий».
} 
«nусть и не по своей вине» и свелось все, что означенная «общественность» усвоила из того, что она о себе не знала или не хотела знать.

С другой стороны, президент Объединения бывших военнопленных Г.А. Хольный по горячим следам тогда напоминал: «...Поторопитесь! Указ должен начать работать, пока ещче живы люди, которых он касается, пока еще возможно хоть немного исправить причиненное зло» [Советские военнопленные... 1995]. Ему вторил со своим мрачным прогнозом другой военнопленный, Н.И. Черкизов: «Боюсь, что наши чиновники будут

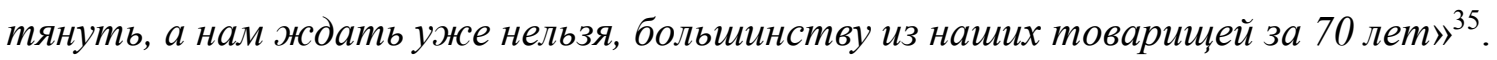

Эти отклики имеют в виду и материальную сторону вопроса, коль скоро указ вменял в обязанность Правительству РФ «рассмотреть вопрос о распространении на бывиих советских военнопленных условий и порядка выплаты компенсачий лицам, подвергшимся нацистским преследованиям, установленных постановлением Правительства РФ от 2 августа 1994 года, с отнесением этих расходов за счет средств Фонда взаимопонимания и примирения либо изыскания других источников финансирования».

Правительство России решения этого вопроса даже и не искало. Предусмотренных указом Ельцина государственных или «других источников финансирования» в экономической реальности России не было и нет.

Не вспомнил о них (ни разу!) и Российский организационный комитет «Победа», хотя президентского указа ни сам Ельцин, ни его преемник не отменяли.

А его надо бы просто-напросто выполнить, заранее заложив под это средства в федеральном бюджете хотя бы на юбилейный год.

Но мрачный оракул предсказал все верно: «Правительство России пока так и не нашло решения вопроса, за счет чьих средств (Фонда или иных источников финансирования) будут отнесены расходы на выплату компенсации бывщим советским военнопленным» ${ }^{36}$.

Число же потенциальных претендентов уменьшалось стремительно - и даже не на радость казне, а при полном ее, несмотря на «тучные годы», равнодушии.

\section{ОФИЦИАЛЬНАЯ КОМПЕНСАЦИЯ БЫВШИМ СОВЕТСКИМ ВОЕННОПЛЕННЫМ ГЕРМАНСКОЙ СТОРОНОЙ (2015-2016 ГГ.)}

На протяжении многих лет обсуждался вопрос о компенсационных выплатах бывшим советским военнопленным за принудительный труд германской стороной. Германия постоянно отказывалась от таких выплат. Основной юридический аргумент перенацеливал возможные притязания бывших военнопленных в адрес собственного государства, которому Германия в свое время выплачивала репарации (бывшим военнопленным, как известно, не досталось ни копейки из репарационного пирога). Имеется множество

\footnotetext{
${ }^{35}$ Из письма Н.И. Черкизова в газету «Российские вести» [Советские военнопленные... 1995].

${ }^{36}$ Цит. из письма Т.П. Казатуровой Г.А. Хольному от 29 февраля 1996 г. 
оснований - и правовых, и этических - оспаривать такую позицию Германии, но это отдельный вопрос, не относящийся к теме настоящей статьи. Мы упоминаем здесь об этом только потому, что совсем недавно Германия неожиданно изменила свою позицию и выразила готовность выплачивать компенсацию!

Бюджетный комитет Бундестага предложил (и сам Бундестаг на слушаниях 18 мая 2015 г. единодушно одобрил) заложить в бюджет Германии компенсацию бывшим советским военнопленным на сумму в 10 млн евро, исходящую из единовременной выплаты в 2500 евро на претендента из ориентировочного числа 4000 потенциальных претендентов.

30 сентября Министерство финансов ФРГ издало «Инструкцию о правомочии бывших советских военнопленных на выплату им компенсаций». Правомочны на это бывшие военнослужащие Красной Армии, взятые вермахтом в плен между 22 июня 1941 г. и 8 мая 1945 г. Правомочие не подразумевает правовой обязательности и правосудности. Размер компенсаций составляет 2500 евро [Bekanntmachung der 2015]. Интервал времени подачи соответствующих заявлений - не ранее 20 мая 2015 г. и не позднее 30 сентября 2017 г.

Право на компенсацию носит сугубо личный характер и не передается по наследству, однако в случае, если претендент умер, но успел лично подать заявление, его прямые наследники правомочны на ее получение, при условии, что они заявят о себе в течение полугода со дня смерти претендента. Иные формы наследования не предусмотрены. Если претендент уже получил компенсацию ранее (как узник концлагерей, например) - это не препятствие. Препятствием могут послужить только замешанность в военных преступлениях (де-факто - коллаборационизм) или сообщение о себе заведомо недостоверных данных (так, возможен и отзыв компенсации через суд).

Нет ни единого указания на то, что обсуждаемая компенсация - на самом деле никакая не компенсация, а гуманитарный жест или гуманитарное урегулирование. Тем самым решение Бундестага от 20 мая 2015 г., принятое после исторической экспертизы, это юридический прецедент, одновременно означающий: вся предыдущая политика Германии в вопросах о компенсации (точнее, не-компенсации!) бывшим советским военнопленным не только позорна, но и беззаконна. Впрочем, и само это решение, принятое так поздно - спустя 70 лет после завершения войны - и имеющее своей целевой группой беспомощных 90-летних и более стариков, - тоже весьма запоздалое и довольно циничное.

Тем не менее оно выполняется.

Миссия Министерства Финансов ФРГ - организация, координация и надзор за деятельностью рабочего исполнительного органа - оператора компенсаций советским военнопленным, каковым назначено Федеральное управление центральных служб и открытых имущественных вопросов (Bundesamt für zentrale Dienste und offene Vermögensfragen или BADV), выполнявшее аналогичные функции при выплате пенсий бывшим узникам гетто. В ведомстве создана соответствующая рабочая группа (руководитель - г-жа Хампель), создана телефонная горячая линия для заявителей (+49.30.1870301550). Ассистировали BADV германские дипломатические 
представительства, которые разместили на своих сайтах скупую информацию о выплатах (в Казахстане, впрочем, посольства потратились и на объявления в газетах на правах рекламы). Трудно себе представить, чтобы 90-летние старики начинали свой день с просмотра посольских сайтов! Так что эффект от такой формальной рекламы был исчезающе мал. Реальными операторами этой новости стали общественные организации Германии, России, Украины и Белоруссии, уведомившие о компенсации бывших военнопленных рассылками по своим базам данных.

Улов, однако, был не слишком велик. По данным пресс-секретаря BADV Ж. Бессе, по состоянию на 12 сентября 2016 г., вместо ожидавшихся 4000 в BADV поступило лишь около 1500 заявлений, из них положительно рассмотрено около 900. Около 400 заявлений не подкреплены никакими документами и ждут досылки; стало быть, отрицательные ответы получили около 200 заявителей (очень любопытно было бы узнать, по каким критериям). Больше половины заявлений поступило из России (800), далее следуют Украина (328), Армения (121), Белоруссия (111), Грузия (64), Казахстан (33) и Азербайджан (14). Выплаты осуществляются, как правило, на банковские счета самих бывших советских военнопленных, а в случае отсутствия таких счетов - на счета их детей. Тем не менее самые первые выплаты были осуществлены еще в начале 2016 г. [Ostermann 2016].

Никакого общественного резонанса на постсоветском пространстве выплата Германией компенсации бывшим советским военнопленным не вызвала.

\section{Список использованных сокращений:}

АВП - Архив внешней политики РФ.

BAP - Bundesarchiv Potsdam.

ГАРФ - Государственный архив РФ.

OKB - Oberkommando der Wehrmacht

$\mathrm{OKX}(\mathrm{OKH})$ - Oberkommando des Heeres

РГАНИ - Российский государственный архив новейшей истории.

РГВА - Российский государственный военный архив.

ЦАМО - Центральный архив Министерства обороны РФ.

BA/MA - Bundesarchiv / Militärarchiv, Freiburg.

\section{ЛИТЕРАТУРА}

Арзамаскин Ю.Н. (1999). Репатриация советских и иностранных граждан в 1944-1953 гг.: военно-политический аспект. М.: Военный ун-т: 248.

Буковский В.К. (1996). Московский процесс. М.: Русская мысль.

Великая отечественная война 1941-1945 годов. В 12 тт. (2011-2015). М.: Кучково поле. 
Гриф секретности снят. Потери вооруженных сил СССР в войнах, боевых действиях и военных конфликтах: Стат. исслед. (1993) / Под общ. ред. Г.Ф. Кривошеева. М.: Воениздат: $416 \mathrm{c.}$

Дугас И.А., Ф.Я. Черон (1994). Вычеркнутые из памяти. Советские военнопленные между Гитлером и Сталиным // Исследования новейшей русской истории. Т.11. Париж: YMCA-Press. 433 c.

Земсков В.Н. (1993). Репатриация советских граждан в 1945-1946 годах. Опираясь на документы // Россия XXI. № 5: 74-81.

Советские люди в Европейском сопротивлении. Воспоминания и документы (1991) / Н.П. Комолова (ред.). Часть I: В партизанском движении; Часть II: Противостояние фашизму в нацисткой неволе. М.: Институт всеобщей истории АН СССР: 464

Марьяновский М.Ф., И.С. Соболь (1997). Павшие... (Вместо предисловия) // Книга памяти воинов-евреев в боях с нацизмом. 1941-1945. Т. IV. М: 9-41.

Полян П.М. (1996). Жертвы двух диктатур. Военнопленные и остарбайтеры в Третьем Рейхе и их репатриация. М.: Ваш выбор: 443 с.

Полян П.М. (2002). Жертвы двух диктатур. Жизнь, труд, унижение и смерть советских военнопленных и остарбайтеров на чужбине и не родине. М.: Росспэн: 898 с.

Полян П.М. (2006). Советские военнопленные-евреи - первые жертвы Холокоста в СССР // Обреченные погибнуть. Судьба советских военнопленных-евреев во Второй мировой войне. Воспоминания и документы. М.: Новое издательство: 9-70.

Полян П.М. (2010). Стратоцидные и стратоциидальные аспекты политики Третьего рейха по отношению к советским военнопленным // Война на уничтожение. Нацистская политика геноцида на территории Восточной Европы. Материалы международной научной конференции. М.: Фонд «Историческая память»: 146-157.

Решин Л. Е. (1994). Коллаборационисты и жертвы режима // Знамя. №8: 158-179.

Россия и СССР в войнах XX века. Потери вооруженных сил. Статистическое исследование (2001) / Под общей ред. Г.Ф. Кривошеева. М.: Олма-пресс: 606 с.

Свердлов Ф.Д. (сост.) (1996). Документы обвиняют. Холокост: свидетельства Красной Армии. М.

Свердлов Ф.Д. (2002). Энциклопедия еврейского героизма. М.: Дограф: 504 с.

Семиряга М.И. (1970). Советские люди в Европейском Сопротивлении. М.: Наука: 352 с.

Соколов Б.В. (1998). Правда о Великой Отечественной войне: сборник статей. СПб.: Алетейя.

Советские военнопленные: справедливость обретена, но кто же об этом знает? (1995) // Российские вести. 3 февраля.

Черноглазова Р.А. (1996). Фашистские лагеря для советских военнопленных на территории Белоруссии // Трагедия плена. Красногорск: 122-125.

Шапиро Г.С., С.Л. Авербух (1997). Очерки еврейского героизма. В 3-х тт. Киев, ТельАвив.

Шевяков А.А. (1994). Репатриация советского мирного населения и военнопленных, оказавшихся в оккупационных зонах государств антигитлеровской коалиции // Население России в 1920-1950-е годы: численность, потери, миграции. Сб. науч. трудов. М.: 195-222. 
Шнеер А. (2003). Плен. В 2-х тт. Иерусалим.

Arad Y. (1993). Soviet Jews in the War against Nazi Germany // Yad Vashem Studies. Vol.XXIII. Jerusalem: 125.

Axworthy M. (1995). Third Axis Fourth Ally Romanian Armed Forces in the European War, 1941-1945. London: Arms \& Armour: 416.

Berkoff K. (2001). The „Russian“ Prisoners of War as Victims of Geniciidal Massacre // Holocaust and Genocide Studies. Spring. Vol.15. №.1: 1-32.

Bekanntmachung der Richtlinie über die Anerkennungsleistung an ehemalige sowjetische Kriegsgefangene (ASK-Anerkennungsrichtlinie) (2015). V.30.9.2015 (Dok. Nr. BANZ AN.10.2015 B1).

Dallin A.J. (1958). Deutsche Herrschaft in Russland 1941-1945. Eine Studie über Besatzungspolitik. Düsseldorf: Droste Verlag: 727.

Dutu A., F. Dobre, L. Loghin (1999). Armata Română în al doilea război mondial (1941-1945). Dicţionar encyclopedic. Bucureşti: Editura enciclopedică.

Gerlach Ch. (1999). Kalkulierte MordeDie deutsche Wirtschafts- und Vernichtungspolitik in Weißrußland 1941 bis 1944. Hamburg: Hamburger Edition: 1232.

Hilberg R. (1999). Der Vernichtungskrieg der europäischen Juden. Bd. 1-3. Frankfurt am Main: Fischer Tashenbuchverlag: 1351.

Krakowski Sh. (1992). The fate of the Jewish POWs of the Soviet and Polish Armies // The Shoah and The War / A. Cohen, Y. Cochavi, Y. Gelber, eds. Studies on the Shoah, Vol. 3. Tel-Aviv: Institute for Research of the Shoah: 217-230. Kriegstagebuch des Oberkommando der Wehrmacht (1982). München.

Ostermann D. (2016). Wenn die Reue zu spät kommt. Vor knapp einem Jahr wurde ehemaligen sowjetischen Kriegsgefangenen eine Entschädigung zugesprochen, doch bislang haben nur acht Betroffene das Geld erhalten // Badische Zeitung. 18 Januar.

Otto R. (2002). Sowjetische Kriegsgefangene. Neue Quellen und Erkenntnisse// Quinkert B. (Hrsg). Wir sind die Herren dieses Landes“. Ursachen, Verlauf und Folgen des deutschen Überfalls auf die Sowjetunion. Hamburg: VSA-Verlag: 124-135.

Overmans R., A. Hilger, P. Polian in Zusammenarbeit mit R. Otto und C. Kretschmer (2012). Rotarmisten in deutscher Hand. Dokumente zu Gefangenschaft, Repatriierung und Rehabilitierung sowjetischer Soldaten des Zweiten Weltkrieges: Padeborn - München Wien - Zürich: Verlag Ferdinand Schöning.

Polyan P. (2005). First Victims of the Holocaust: Soviet-Jewish Prisoners of War in German Captivity // Kritika: Explorations in Russian and Eurasian History. Fall Vol.6. 4: 763-787.

Roschmann H. (1982). Gutachten zur Behandlung und zu den Verlusten sowjetischer Kriegsgefangener in deutscher Hand von 1941-1945 und zur Bewertung der sogenannten «Documents NOKW 2125» (Nachweisung des Verbliebs der sowjetischen Kriegsgefangenen nach dem Stande vom 1.5.1944). Ingolstadt: Zeitgeschichtliche Forschungsstelle Indolstadt: 54.

Streit Ch. (1991). Keine Kameraden: die Wehrmacht und die sowjetischen Kriegsgefangenen 1941-1945. Bonn: Verlag J.H.W.Dietz Nachf.: 448.

Ueberschär G.R., Wette W. (Hg.) (1984). Der deutsche Überfall auf die Soviet Union. "Unternehmen Barbarossa" 1941. Frankfurt-am-Main: Fischer Taschenbuch Verlag: 419. 


\title{
SOVIET PRISONERS OF WAR: HOW MANY WERE THERE AND HOW MANY CAME HOME?
}

\section{PAVEL POLYAN (Polian) ${ }^{1, *}$}

\begin{abstract}
The paper discusses demographic aspects of the captivity of Red Army servicemen during World War II, such as the number of prisoners of war in Germany, Finland and Romania, the mortality rate in captivity and data on repatriation. Soviet prisoners of war of Jewish ethnicity, who de facto became the first victims of the Holocaust after June 22, 1941, are considered as a separate subcategory.
\end{abstract}

Keywords: Captivity, Soviet Prisoners of War, Soviet Prisoners of War of Jewish Origin, Holocaust, Mortality in Captivity, Repatriation, Compensation.

\footnotetext{
${ }^{1}$ Institute OF GEOGRAPHY, RUSSIAN ACADEMY OF SCIENCES (RUSSiA).

*CORRESPONDENCE: PAVEL.POLIAN@GMAIL.COM

DATE RECEIVED: MARCH 2016.
}

\section{REFERENCES}

Arad Y. (1993). Soviet Jews in the War against Nazi Germany // Yad Vashem Studies. Vol.XXIII. Jerusalem: 125.

Arzamaskin Yu.N. (1999). Repatriatsiya sovetskikh i inostrannykh grazhdan v 1944-1953 gg.: voenno-politicheskiy aspekt [Repatriation of Soviet and foreign citizens in 1944-1953: The military-political aspect]. Moscow.

Axworthy M. (1995). Third Axis Fourth Ally Romanian Armed Forces in the European War, 1941-1945. London: Arms \& Armour: 416.

Bekanntmachung der Richtlinie über die Anerkennungsleistung an ehemalige sowjetische Kriegsgefangene (ASK-Anerkennungsrichtlinie) (2015). V.30.9.2015 (Dok. Nr. BANZ AN.10.2015 B1).

Berkoff K. (2001). The „Russian“ Prisoners of War as Victims of Geniciidal Massacre // Holocaust and Genocide Studies. Spring. Vol.15. №.1: 1-32.

Bukovsky V.K. (1996). Moskovskiy protses [The Moscow trial]. Moscow: Russkaya mysl'.

Chernoglazova R. A. (1996). Fashistskie lagerya dlya sovetskikh voennoplennykh na territorii Belorussii [Nazi camps for Soviet prisoners of war in the territory of Belarus] // Tragediya plena [The tragedy of captivity]. Krasnogorsk: 122-125.

Dallin A.J. (1958). Deutsche Herrschaft in Russland 1941-1945. Eine Studie über Besatzungspolitik. Düsseldorf: Droste Verlag: 727.

Dugas I.A., F.Ya. Cherone (1994). Vycherknutye iz pamyati. Sovetskie voennoplennye mezhdu Gitlerom i Stalinym [To erase from memory. Soviet prisoners of war between Hitler and Stalin]. T.11 [Vol.11]. Paris: YMCA-Press. 433 p.

Dutu A., F. Dobre, L. Loghin (1999). Armata Română în al doilea război mondial (1941-1945). Dicţionar encyclopedic. Bucureşti: Editura enciclopedică.

Gerlach Ch. (1999). Kalkulierte Morde. Die deutsche Wirtschafts- und Vernichtungspolitik in Weißrußland 1941 bis 1944. Hamburg: Hamburger Edition: 1232. 
Grif sekretnosti snyat. Poteri vooruzhennykh sil SSSR v voynakh, boyevykh deystviyakh i voyennykh konfliktakh [Secrecy label removed. Casualties of the armed forces of the USSR in wars, hostilities and military conflicts] (1993). G.F.Krivosheev, ed. Moscow: Voenizdat: $416 \mathrm{p}$.

Hilberg R. (1999). Der Vernichtungskrieg der europäischen Juden. Bd. 1-3. Frankfurt am Main: Fischer Tashenbuchverlag: 1351.

Krakowski Sh. (1992). The fate of the Jewish POWs of the Soviet and Polish Armies // The Shoah and The War/ A. Cohen, Y. Cochavi, Y. Gelber, eds. Studies on the Shoah, Vol. 3. Tel-Aviv: Institute for Research of the Shoah: 217-230. Kriegstagebuch des Oberkommando der Wehrmacht (1982). München.

Maryanovsky M.F., I.S. Sobol (1997). Pavshie... (Vmesto predisloviya) [Fallen ... (Instead of the foreword)] // Kniga pamyati voinov-evreev v boyakh s natsizmom. 1941-1945 [Memory Book of Jewish soldiers in the battle against Nazism. 1941-1945]. T. IV [Vol. IV]. Moscow: 9-41.

Ostermann D. (2016). Wenn die Reue zu spät kommt. Vor knapp einem Jahr wurde ehemaligen sowjetischen Kriegsgefangenen eine Entschädigung zugesprochen, doch bislang haben nur acht Betroffene das Geld erhalten // Badische Zeitung. 18 Januar.

Otto R. (2002). Sowjetische Kriegsgefangene. Neue Quellen und Erkenntnisse// Quinkert B. (Hrsg). Wir sind die Herren dieses Landes". Ursachen, Verlauf und Folgen des deutschen Überfalls auf die Sowjetunion. Hamburg: VSA-Verlag: 124-135.

Overmans R., A. Hilger, P. Polian in Zusammenarbeit mit R. Otto und C. Kretschmer (2012) . Rotarmisten in deutscher Hand. Dokumente zu Gefangenschaft, Repatriierung und Rehabilitierung sowjetischer Soldaten des Zweiten Weltkrieges: Padeborn - München Wien - Zürich: Verlag Ferdinand Schöning.

Polyan P. (2005). First Victims of the Holocaust: Soviet-Jewish Prisoners of War in German Captivity // Kritika: Explorations in Russian and Eurasian History. Fall Vol.6. 4: 763-787.

Polyan P.M. (2010). Stratotsidnye i stratotsiidal'nye aspekty politiki Tret'ego reykha po otnosheniyu k sovetskim voennoplennym [Stratocidal and stratotsiidal-like aspects of the policy of the Third Reich towards the Soviet prisoners of war] // Voyna na unichtozhenie. Natsistskaya politika genotsida na territorii Vostochnoy Evropy. Materialy mezhdunarodnoy nauchnoy konferentsii [The war of annihilation. The Nazi policy of genocide in Eastern Europe. Proceedings of the international scientific conference]. Moscow: Fond «Istoricheskaya pamyat'»: 146-157.

Polyan P.M. (1996). Zhertvy dvukh diktatur. Voennoplennye i ostarbaytery v Tret'em Reykhe i ikh repatriatsiya [Victims of Two Dictatorships. Prisoners of war and Ostarbaiter in the Third Reich and their repatriation]. Moscow: Vash vybor.

Polyan P.M. (2002). Zhertvy dvukh diktatur. Zhizn', trud, unizhenie i smert' sovetskikh voennoplennykh i ostarbayterov na chuzhbine i na rodine [Victims of two dictatorships. Life, work, humiliation and death of Soviet prisoners of war and ostarbeiters in a foreign land and at homeland]. Moscow: Rosspen: 898 p.

Polyan P.M. (2006). Sovetskie voennoplennye-evrei - pervye zhertvy Kholokosta v SSSR [Soviet Jewish prisoners - the first victims of the Holocaust in the USSR] // Obrechennye pogibnut'. Sud'ba sovetskikh voennoplennykh-evreev vo Vtoroy mirovoy voyne.

Vospominaniya i dokumenty [Destined to die. The fate of soviet Jewish prisoners in World War II. The memories and documents]. Moscow: Novoe izdatel'stvo: 9-70. 
Reshin L. E. (1994). Kollaboratsionisty i zhertvy rezhima [Collaborators and victims of the regime] // Znamya [Banner]. №8: 158-179.

Roschmann H. (1982). Gutachten zur Behandlung und zu den Verlusten sowjetischer Kriegsgefangener in deutscher Hand von 1941-1945 und zur Bewertung der sogenannten «Documents NOKW 2125» (Nachweisung des Verbliebs der sowjetischen Kriegsgefangenen nach dem Stande vom 1.5.1944). Ingolstadt: Zeitgeschichtliche Forschungsstelle Indolstadt: 54.

Rossiya i SSSR v voynakh XX veka. Poteri vooruzhennykh sil. Statisticheskoe issledovanie [Russia and the USSR in the wars of the XX century. Casualties of the armed forces. Statistical research] (2001) / Pod obshchey red. G.F. Krivosheeva [G. F. Krivosheev, ed.]. Moscow: Olma-press: 606 p.

Schneier A. (2003). Plen. V 2-kh tt. [Captivity. In 2 vols]. Jerusalem.

Semiryaga M.I. (1970). Sovetskie lyudi v Evropeyskom Soprotivlenii [The Soviet people in the European Resistance]. Moscow: Nauka: 352 p.

Shapiro G.S., S.L. (1997). Ocherki evreyskogo geroizma. V 3-kh tt. T.3 [Sketches of Jewish heroism. In 3 vols. V.3]. Kiev, Tel Aviv.

Sheviakov A.A. (1994). Repatriatsiya sovetskogo mirnogo naseleniya i voennoplennykh, okazavshikhsya v okkupatsionnykh zonakh gosudarstv antigitlerovskoy koalitsii// Naselenie Rossii v 1920-1950-e gody: chislennost', poteri, migratsii. Sb. nauch. trudov [Repatriation of Soviet civilians and prisoners of war, caught up in the occupation zones of the anti-Hitler coalition states]. Moscow: 195-222.

Sokolov B.V. (1998). Pravda o Velikoy Otechestvennoy voyne: sbornik statey [The truth about the Great Patriotic War. A collection of articles]. St. Petersburg: Aleteyya.

Sovetskie lyudi v Evropeyskom soprotivlenii. Vospominaniya i dokumenty [The Soviet people in the European resistance. The memories and documents] (1991) / N.P. Komolova (red.) [N. P. Komolova, ed.]. Chast' I: V partizanskom dvizhenii; Chast' II: Protivostoyanie fashizmu v natsistkoy nevole [Part I: The partisan movement; Part II: The opposition to fascism in Nazi captivity]. Moscow: Institut vseobshchey istorii AN SSSR: 464.

Sovetskie voennoplennye: spravedlivost' obretena, no kto zhe ob etom znaet? [Soviet prisoners of war: justice is acquired, but who knows about this?] (1995) // Rossiyskie vesti. 3 February.

Streit Ch. (1991). Keine Kameraden: die Wehrmacht und die sowjetischen Kriegsgefangenen 1941-1945. Bonn: Verlag J.H.W.Dietz Nachf.: 448.

Sverdlov F.D. (2002). Entsiklopediya evreyskogo geroizma [Encyclopedia of Jewish heroism]. Moscow: Dograf: 504 p.

Sverdlov F.D. (compiler) (1996). Dokumenty obvinyayut. Kholokost: svidetel'stva Krasnoy Armii [The documents accuse. Holocaust: the testimony of the Red Army]. Moscow.

Ueberschär G.R., Wette W. (Hg.) (1984). Der deutsche Überfall auf die Soviet Union. "Unternehmen Barbarossa" 1941. Frankfurt-am-Main: Fischer Taschenbuch Verlag: 419.

Velikaya otechestvennaya voyna 1941-1945 godov. V 12 tt. [The Great Patriotic War of 19411945. In 12 volumes] (2011-2015). Moscow.

Zemskov V.N. (1993). Repatriatsiya sovetskikh grazhdan v 1945-1946 godakh. Opirayas' na dokumenty [The repatriation of Soviet citizens in 1945-1946. Based on the documents] // Rossiya XXI. № 5: 74-81. 